\title{
Simbolisasi Etnik Muna di Bandung: Studi Identitas Etnik Orang Muna
}

\author{
Sumadi Dila
}

\begin{abstract}
The important thing of openness attitude, tolerance and communication skill that are different in cultural at urban complex community is the successful key to make closer living in harmony side by side. This research is aimed to understant and to explain yhe interaction and the communication of Muna people in relating with their ethnic identity in cociety in Bandung. The result of research finds the constuction mechanism of Muna ethnic identity through the self strengthening, evaluation, dialogue, adaptation, and structuring that form Muna ethnic categiries of

Regionalism, Prgmatic, and Religious. This research also find the accentuation of symbols, setting, and ethnic identity using in expressive and impressive manner based on personality (individual) and social. The identity of regionalism Muna ethnic as the past self consept is'n dominant anymore, on the contrary the identity of pragmatic Muna and relgious Muna ethnic are showed more often as the present self concept based on new situation. That's done to complete the self adaptation in fostering the community awareness and acceptance.
\end{abstract}

Kata kunci: komunikasi, budaya, identitas etnik

\section{Pendahuluan}

\subsection{Latar Belakang}

Fenomena interaksi dan komunikasi antaretnik pendatang dan etnik Sunda di kota Bandung dalam konteks budaya telah berlangsung sejak lama. Perjumpaan berbagai etnik dengan budaya yang berbeda menjadi bagian keseharian masyarakat di kota Bandung. Di antara sekian banyak warga dan etnis pendatang yang hidup menetap dan bekerja di kota Bandung adalah etnik Muna, yang merupakan salah satu dari 12 suku bangsa di Sulawesi Tenggara. Sejak awal kedatangannya sampai dengan saat ini, orang Muna memperlihatkan kecenderungan intensitas dalam berinteraksi dan berkomunikasi dengan semua etnik, khususnya etnik Sunda sebagai warga mayoritas di kota Bandung.

Proses komunikasi yang berlangsung dari kedua etnik tersebut, membentuk jalinan komunikasi budaya yang erat dan dinamis dalam kehidupan sehari-hari. Meski pada awal kedatangannya di Bandung, orang Muna memilih hidup berkelompok atau berkumpul dengan sesama etniknya, namun pada perkembangan selanjutnya, kondisi itu mulai bergeser dan beralih untuk hidup secara membaur dengan masyarakat kebanyakan, khususnya orang Sunda. Seiring dengan itu berbagai hal terkait dengan kesadaran dan pengalaman mereka memengaruhi pikiran, sikap, 
dan perilaku bahkan sistem simbol dan identitas etnik mereka.

Jika pada awal kedatangannya, semangat kebersamaan etnik Muna terus diperlihatkan, dipertahankan, dan dipelihara, dalam diri sebagai identitas etnik asal mereka, maka selang beberapa lama hal itu mulai terkikis oleh perjalanan waktu, situasi dan kesibukan mereka dalam kehidupan bermasyarakat. Kondisi ini selanjutnya berakibat pada perwujudan dan pengungkapan makna kultural etnik Muna dan makna kontekstual di antara orang Muna secara berbeda-beda pada interaksi mereka baik dalam keluarga, komunitas Muna maupun pada masyarakat luas. Bahkan, bersamaan dengan itu, batas-batas etnik asal Muna mulai longgar, seiring tingginya persentuhan, dan komunikasi mereka dengan simbol-simbol budaya orang Sunda di masyarakat. Konsep diri yang lalu sebagai identitas etnik asal kemudian tersituasikan menjadi diri kekinian yang berdasarkan pada keadaannya saat ini.

Beberapa hal yang dapat ditunjukkan persentuhan, interaksi, dan komunikasi orang Muna dengan orang Sunda, yakni lokasi pemukiman yang membaur, perkawinan campuran dengan etnik Sunda yang mencapai $60 \%$, pengurus organisasi profesi tertentu, termasuk organisasi berlatar etnik di Bandung, (Data penelitian, 2008). Kondisi ini mengindikasikan intensitas pergaulan sosial orang Muna yang luas, dan adanya sikap keterbukaan, toleransi, partisipasi, dan penyesuaian diri orang Muna dalam beraktivitas di masyarakat. Dengan demikian, keberadaan mereka saat ini secara geografis, sosial, maupun budaya, mengalami proses penyesuaian dan penataan diri dalam hal konstruksi identitas etniknya yang baru. Pada batas ini, nilai-nilai budaya etnik asal sebagai kaum minoritas di satu sisi, berhadapan dengan nilainilai budaya etnik Sunda mayoritas pada sisi yang lain.

Hal-hal tersebut kemudian menjadi alasan khusus orang Muna menghargai perbedaan budaya, sekaligus melakukan akomodasi dan peminjaman budaya (cultural borowing) luar di lingkungannya yang baru. Karenanya, berbagai pikiran, pandangan, dan perilaku orang Muna sebagai kelompok etnik di Bandung, menjadi kompleks hingga membentuk kesadaran dan pengalaman baru dalam diri mereka. Proses interaksi mereka dalam konteks komunikasi budaya, membentuk kategori etnik dengan simbol - simbol verbal/nonverbal, dan setting khusus dalam menampilkan identitas etniknya. Walhasil, pengguna identitas etnik asal sebagai diri yang lalu, kemudian berhadapan dengan pilihan identitas tambahan yang baru sebagai diri kekinian dalam diri mereka. Fenomena ini mirip dengan penjelasan Fredrik Barth tentang peran skema ethnical dalam pengungkapan dan konstruksi identitas etnik yang tersituasikan.

Sebagai produk dari relasi antarmanusia yang tak berkeputusan antara orang Muna dengan orang Sunda, akhirnya memberi ruang yang cukup bagi terjalinnya komunikasi antarbudaya. Dengan demikian penting diungkap dan dikaji dunia makna mereka termasuk batas identitas etnik asal ataupun identitas tambahan. Dengan cara ini diharapkan dapat ditemukan dan dijelaskan karakteristik kategori etnik Muna secara khusus, dan dapat dikonstruksi model mekanisme identitas etnik yang terbentuk dan dipergunakan orang Muna di kota Bandung.

\subsection{Rumusan Masalah}

Berdasarkan alasan uraian dan alasan yang disebutkan dalam latar belakang penelitian, maka rumusan masalah penelitian ini dapat kemukakan sebagai berikut: (1) Bagaimana orang Muna mengidetifikasi identitas etniknya ketika berinteraksi dengan orang Sunda atau etnik lain di kota Bandung? (2) Bagaimana proses simbolisasi verbal dan nonverbal orang Muna dalam berbagai peristiwa komunikasi di kota Bandung? (3) Bagaimanakah setting komunikasi dibentuk dan dipergunakan orang Muna dalam interaksi sosialnya di kota Bandung? (4) Bagaimanakah orang Muna mempergunakan identitas ke-etnikannya dengan orang Sunda atau etnik lain di Kota Bandung? 


\subsection{Kajian Pustaka}

\subsubsection{Komunikasi, Budaya, dan Identitas Etnik}

Kajian ini berusaha memahami dan menjelaskan relasi komunikasi, budaya, dan identitas etnik dalam interaksi sosial dalam masyarakat. Hubungan antara komunikasi, budaya hingga terbentuknya identitas etnik dalam proses interaksi sosial di masyarakat. Dalam banyak studi dan kepustakaan ilmiah, penjelasan tentang konsep komunikasi, budaya, dan identitas etnik telah banyak diungkap. Namun, sekadar menyegarkan ingatan kembali, akan dijelaskan berturut-turut pengertian ketiga konsep tersebut secara singkat. Tubbs dan Moss (1994:6) mendefinisikan komunikasi sebagai proses penciptaan makna antara dua orang atau lebih. Sementara, Levine dan Adelman yang dikutip Mulyana (2004:3) memberikan pengertian komunikasi sebagai proses berbagi makna melalui perilaku verbal dan nonverbal, yang melibatkan dua orang atau lebih.

Sedangkan Gudykunst dan Kim (1992:13-14) mendefinisikan komunikasi (antarbudaya) sebagai proses transaksional, simbolik yang melibatkan pemberian makna antara orang-orang (dari budaya yang berbeda). Dengan demikian, komunikasi dapat terjadi jika suatu sumber membangkitkan respons pada penerimaan melalui penyampaian pesan dalam bentuk tanda atau simbol baik dalam bentuk verbal (kata-kata) dan nonverbal, melibatkan peserta (orang-orang), tanpa harus memastikan kedua pihak yang berkomunikasi memiliki sistem simbol yang sama. Menurut Hofstede (1994:7) simbol terdiri atas kata, jargon, isyarat, gambar, pakaian, penampilan atau objek simbol status yang mengandung suatu makna tertentu yang hanya dikenali oleh mereka yang menganut suatu budaya.

Hofstede menyebutkan bahwa budaya yang terdiri atas nilai-nilai adalah inti dari suatu budaya, simbol-simbol, dan ritual merupakan manifestasi budaya, yang dipraktikkan dan memiliki makna. Sementara, menurut Trenholm dan Jensen yang dikutip Mulyana (2004: 15), mendefinisikan budaya sebagai seperangkat nilai, kepercayaan, norma, dan adat-istiadat, aturan-aturan, dan kode yang secara sosial mendefinisikan kelompok orang, mengikat mereka satu sama lain, dan memberi kesadaran bersama. Melalui budaya persepsi tentang dunia, realitas, dan cara berpikir tentang diri sendiri, orang lain, hubungan kita dengan orang lain, cara mencapai tujuan dan cara mempertukarkan pesan, dapat memandu kita. Dengan kata lain, menurut Goodman (1994:40), budaya manusia telah berkembang hingga ke titik yang memungkinkan budaya menggantikan naluri dalam menentukan setiap pikiran dan tindakan.

Dengan demikian, hubungan komunikasi dan budaya dapat dilihat dari penjelasan Alfred G. Smith yang dikutip Mulyana (2004 : 14), budaya adalah kode yang kita pelajari bersama dan untuk itu dibutuhkan komunikasi. Komunikasi membutuhkan pengkodean dan simbol-simbol yang harus dipelajari, sehingga melibatkan ekspektasi, persepsi, pilihan tindakan, dan penafsiran yang dipengaruhi oleh lingkungan budaya tertentu. Edward T. Hall (1996: 36-53) menyebut hal ini sebagai dua entitas penting yang tak terpisahkan, budaya adalah komunikasi dan komunikasi adalah budaya. Budaya muncul melalui komunikasi dan menjadi bagian dari perilaku komunikasi, serta komunikasi pun pada akhirnya turut menentukan, memelihara, mengembangkan atau mewariskan budaya.

Artinya, budaya menuntun individu atau masyarakat cara berkomunikasi, baik verbal dan nonverbal. Dengan demikian, setiap praktik komunikasi pada dasarnya adalah suatu representasi budaya atau suatu peta atas realitas (budaya) yang sangat rumit. Peran komunikasi dalam proses interaksi antarbudaya sampai kepada pembentukan identitas diri seseorang, kelompok, atau etnik, dimaksudkan dalam rangka pertukaran (exchange) dan berbagi makna (sharing meaning) pada simbol-simbol yang disampaikan antara individu-individu. Menurut Porter dan Samovar seperti yang dikutip Liliweri, (2001:159), dengan budaya-lah manusia belajar berkomunikasi, memandang dunianya, membentuk kategorikategori, konsep-konsep, dan label-label khusus tentang dirinya, termasuk identitas etniknya. 
Dengan kata lain, seperti disebutkan W.I. Gorden dan Edward T. Hall (Dilla, 2007:33), suatu kelompok masyarakat tertentu akan memiliki tata cara berbeda dengan kelompok masyarakat lain dalam kehidupan sosial. Maksudnya, masing-masing kategori identitas etnik Muna yang telah kemukakan memperlihatkan perbedaan dalam citra diri dan kosep diri dalam dunia sosial mereka.

Kesamaan atau perbedaan budaya kemudian memengaruhi sistem simbol, pikiran, setting, dan tindakan komunikasi individu hingga membentuk identitas etnik tertentu. Menurut Weinreich (1985), salah satu yang mendorong terbentuknya identitas etnik adalah kesamaan-kesamaan sesama anggota etnik yang terbentuk melalui kesamaan proses belajar, kesamaan pengalaman, dan kesamaan latar belakang, halmana menumbuhkan perasaan seidentitas yang memiliki kesamaan perilaku. Perasaan seidentitas inilah yang mula-mula memunculkan identitas etnik (Suparlan,1999:103). Hal ini sejalan dengan analisis Hogg dan Abram (1988:25) bahwa dalam masyarakat secara hierarkis, terstruktur kategori-kategori sosial yang merupakan penggolongan orang menurut negara, ras, kelas sosial, pekerjaan, jenis kelamin, etnis, agama, dan lain sebagainya. Masing-masing kategori sosial tersebut melekat suatu kekuatan, status, martabat, harapan, dan hubungan antarindividu dan antarkelompok yang memiliki suatu struktur sosial yang khas, hingga terbentuknya identitas etnik.

Identitas etnik dimaksud menurut Phinney dan Alipora (1990) sebuah konstruksi yang kompleks yang mengandung sebuah komitmen dan rasa kepemilikan (sense of belonging) pada kelompok etnik, evaluasi positif pada kelompok, berminat di dalam dan berpengetahuan tentang kelompok, dan turut serta terlibat dalam aktivitas sosial kelompok (Mulyana, 2007:141). Singkatnya, identitas itu berkaitan dengan masa lalu dan aspirasi masa depan yang berhubungan dengan etnisitas, sehingga definisi identitas etniknya bersifat relatif dan berbeda-beda dari situasi ke situasi, yang oleh Fredrik Barth (1988:112) disebut etnik situasional. Barth menggambarkan konsep identitas etniknya sebagai situational ethnical, sebagai suatu keadaan yang tersituasikan oleh kondisi-kondisi tertentu atau khusus yang dianggap penting. Jadi, identitas etnik seseorang tidak berhenti ketika orang ditasbihkan sebagai anggota etnik tertentu melalui bukti darah. Akan tetapi, identitas itu terbentuk melalui sosialisasi keluarga, masyarakat, dan lingkungannya.

Karena itu, pemahaman tentang kebudayaan dan komunikasi suatu individu, kelompok, atau etnik, dalam konteks antarbudaya, akan mampu menjelaskan perilaku komunikasi terkait mekanisme terbentuknya identitas etnik situasional, sistem simbol, atribut, setting, maupun penggunaan identitas etnik. Berangkat dari argumentasi di atas, bahwa proses persinggungan budaya, ataupun perwujudan identitas suatu etnik dalam sistem masyarakat yang multikultur melibatkan seperangkat sisitim simbol verbal dan nonvernal serta setting komunikasi yang memungkinkan individu melakukan interaksi.

\section{Metode Penelitian dan Teknik Pengumpulan Data}

Berhubung penelitian ini mengusung tradisi fenomenologi dengan kerangka teori interaksi simbolik, dramaturgi dan perspektifBarth tentang identitas etnik, maka kajiannya menggunakan paradigma subjektif atau perspektif interpretif. Penelitian ini merupakan studi emik tentang makna perilaku simbolik orang Muna secara subjektif dan mendalam, setting, identitfikasi etnik dan penggunaan identitas etnik dalam interaksi di kota Bandung. Dengan demikian, metode penelitiannya bersifat kualitatif. Subjek penelitiannya orang Muna yang bekerja dan hidup menetap di Bandung, baik sebagai orang Muna keturunan asli Muna maupun orang Muna yang melakukan perkawinan campuran dengan etnik lainnya. Sedangkan objek penelitianya adalah makna dari perilaku orang Muna yang tafsirkan atau dipergunakan yang tersimbolisasikan dalam proses komunikasi baik dalam internal orang Muna maupun secara eksternal dalam masyarakat luas.

Teknik pengumpulan data penelitian dilakukan melalui pengamatan berperan serta (participant 
Terakreditasi Dirjen Dikti SK No. 56/DIKTI/Kep/2005

Tabel.1

Proses Identifikasi identitas etnik orang Muna

\begin{tabular}{|c|c|c|c|}
\hline No & Konteks & Mekanisme & Media sosialisasi \\
\hline 1. & Intraetnik & Peneguhan diri \& Penilaian diri & Keluarga dan komunitas Muna \\
\hline 2. & Antaretnik & $\begin{array}{c}\text { Dialog diri, penyesuaian diri, } \\
\text { dan penataan diri }\end{array}$ & $\begin{array}{c}\text { Partisipasi sosial, organisasi, } \\
\text { lingkungan kerja dll. }\end{array}$ \\
\hline
\end{tabular}

(Sumber, hasil penelitian, 2008)

observer), wawancara mendalam (in-depth interview), dan studi dokumen. Dalam penelitian ini pengumpulan data dimulai dengan pengamatan pendahuluan, yang dilanjutkan dengan pengamatan berperan serta, yakni memasuki kehidupan dan aktivitas orang Muna secara selektif, baik sebagai individu, keluarga, kelompok etnik, maupun sebagai anggota masyarakat selama waktu yang ditentukan. Selanjutnya, untuk kebutuhan wawancara, peneliti memilih 11 orang informan yang ditarik secara purposive dengan teknik snowball, untuk diwawancarai atau dimintai konfirmasi, terkait temuan penelitian, termasuk halhal yang belum terungkap atau belum lengkap. Selain itu, untuk peneliti juga memanfaatkan dokumen foto untuk dianalisis sebagai kelengkapan data penelitian.

\section{Hasil dan Pembahasan}

\subsection{Proses Identitas Etnik}

Proses identifikasi identitas etnik orang Muna di Bandung berlangsung dalam 2 (dua) konteks, mekanisme tahapan yang dilakukan melalui media sosialisasi. Proses tersebut merupakan konstruksi identitas etnik orang Muna, baik dalam konteks intra etniknya maupun antaretnik di Bandung. Mekanisme tersebut meliputi proses komunikasi intrapersonal dan proses komunikasi interpersonal dalam keluarga, komunitas dan masyarakat, seperti pada tabel 1 .

Gambar 1.

Model Kategori Identitas Orang Muna

\begin{tabular}{|c|c|c|c|}
\hline Alasan & Motif & Kategori & Identitas \\
\hline $\begin{array}{l}\text { 1. Keutuhan \& } \\
\text { kebersamaan } \\
\text { etnik Muna } \\
\text { 2. Hamonisasi } \\
\text { hidup } \\
\text { 3. Keseimbangan } \\
\text { dunia \& akhirat }\end{array}$ & $\begin{array}{l}\text { 1.Memperteguh/ } \\
\text { sosialisasi etnik } \\
\text { Muna (masa lalu) } \\
\text { 2.Mengisi \& } \\
\text { memanfa atkan } \\
\text { hidup yang } \\
\text { dijalani, } \\
\text { (kekinian) } \\
\text { 3.Pengabdian diri } \\
\text { totalsebagai } \\
\text { bekal hidup, (mas } \\
\text { datang) }\end{array}$ & $\begin{array}{l}\text { 1. Orang Muna } \\
\text { Masa Lalu } \\
\text { 2. Orang Muna } \\
\text { Masa Kini } \\
\text { (kekinian) } \\
\text { 3. Orang Muna } \\
\text { Masa Datang }\end{array}$ & $\begin{array}{l}\text { 1.Muna } \\
\text { Kedaerahan } \\
\text { 2.Muna } \\
\text { Pragmatis } \\
\text { 3.Muna Religius }\end{array}$ \\
\hline
\end{tabular}


Dalam konteks intra etnik Muna identitfikasi identitas mereka dilakukan melalui peneguhana diri, dan penilaian diri. Sedangkan mekanisme identifikasi identitas etnik dalam konteks di luar etnik Muna melalui partisipasi sosial, berorganisasi, dan lingkungan kerja yang meliputi: dialog diri, penyesuaian diri, dan penataan diri. Mekanisme ini kemudian menjadi representasi pengalaman dan kesadaran diri orang Muna dalam berbagai situasi yang membentuk kategori etnik yang bersifat khusus, yang dipengaruhi situasi dan kehadiran orang-orang baru dan penting (new significant others), sebagai typiction menurut Berger and Luckmann (Mulyana, 2002:235). Kategori etnik tersebut yakni: (1) orang Muna Kedaerahan; (2) orang Muna Pragmatis; dan (3) orang Muna Religius. Ketiga kategori tersebut memperlihatkan adanya keragaman berinteraksi dan keterampilan komunikasi sebagai strategi dan taktik pengelolaan kesan (impression mangemant), baik sesama orang Muna maupun di luar orang Muna. Mengenai alasan dan motif kategori orang Muna hingga membentuk identitas etnik dapat dilihat pada gambar 1 .

\subsection{Proses Simbolisasi Verbal dan Nonverbal}

Simbol komunikasi verbal dan nonverbal orang Muna dalam dalam berbagai peristiwa komunikasi di Bandung, dibagi menjadi dua peristiwa komunikasi, yakni: (1) peristiwa komunikasi dalam komunitas orang Muna; (2) peristiwa komunikasi dengan etnik lainya. Lebih jelasnya, dapat dilihat pada tabel berikut:

Pada peristiwa komunikasi sesama orang Muna, simbol verbal yang menonjol dipergunakan adalah penggunaan kata, istilah, atau bahasa Muna dan bahasa Indonesia, dengan sedikit menggunakan istilah Islami dalam interkasi mereka. Bahkan, atribut etnik seperti penyebutan nama gelar "Ode" dan "La" di depan nama mereka masih dapat ditemukan dan menonjol. Sementara, penggunaan simbol nonverbal seperti nada suara yang lugas, tegas, dan cenderung tinggi, isyarat, dan gerakan tubuh yang dominan, adalah jabatan tangan erat yang menunjukkan hormat dan bersahabat, mencium tangan orang yang lebih tua pertnada bersaudara, berpelukan, dan mencium

Tabel 2

Simbolisasi Verbal dan Nonverbal Orang Muna

\begin{tabular}{|c|l|l|l|}
\hline No & Konteks & \multicolumn{1}{|c|}{ Simbol Verbal } & \multicolumn{1}{c|}{ Simbol Nonverbal } \\
\hline 1. & $\begin{array}{l}\text { Peristiwa komunikasi } \\
\text { Intraetnik (Muna): } \\
\text { Keluarga, pertemuan org } \\
\text { Muna }\end{array}$ & $\begin{array}{l}\text { 1. Kata, istilah / kalimat dalam } \\
\text { bahasa daerah Muna, 2. Kata, } \\
\text { kalimat dalam bahasa Indonesia. } \\
\text { (Terjadi variasi penggunaan } \\
\text { sistim simbol kedua bahasa } \\
\text { tersebut) }\end{array}$ & $\begin{array}{l}\text { 1. Berbicara lugas, tegas, } \\
\text { cenderung keras, tinggi \& } \\
\text { ekspresif, 2. Penyebutan gelar } \\
\text { (ode/la), 3. Jabat tangan erat, } \\
\text { pakaian rapi (jas batik) atau } \\
\text { sedikit motif etrik, kopiah, } \\
\text { berjilbab \& senyum ceria } \\
\text { kekeluargaan. }\end{array}$ \\
\hline 2. & $\begin{array}{l}\text { Peristiwa komunikasi } \\
\text { Antaretnik (Sunda): Lingk } \\
\text { Kerja, kelompok, } \\
\text { organsisasi \& kegiatam } \\
\text { sosial-masyarakat }\end{array}$ & $\begin{array}{l}\text { 1. Kata, istilah/kalimat dalam } \\
\text { bahasa Indonesia, 2. Kata, } \\
\text { kalimat atau istilah dalam } \\
\text { bahasa Sunda. } \\
\text { (Terjadi variasi penggunaan } \\
\text { kedua simbol bahasa tsb) }\end{array}$ & $\begin{array}{l}\text { 1.Berbicara sedikit melembut } \\
\text { merendah secara impresif, 2. } \\
\text { Jabat tangan, berangkulan, } \\
\text { pakain rapih, jas, batik, bleser, } \\
\text { jilbab, kopiah, 3. Senyum ceria- } \\
\text { bersahabat. }\end{array}$ \\
\hline
\end{tabular}

(Sumber, hasil penelitian, 2008) 
Terakreditasi Dirjen Dikti SK No. 56/DIKTI/Kep/2005

Tabel 3

Setting Komunikasi yang Dibentuk dan Penggunaan Orang Muna

\begin{tabular}{|c|c|c|c|}
\hline No & $\begin{array}{c}\text { Orientasi Pengaturan Setting } \\
\text { Komunikasi }\end{array}$ & $\begin{array}{l}\text { Setting Komunikasi } \\
\text { yang Terbentuk \& } \\
\text { dipergunakan }\end{array}$ & Keterangan \\
\hline 1 & $\begin{array}{l}\text { Kesetiaan nilai etnik asal daerah dan } \\
\text { Kehadiran significant others; } \\
\text { keluarga, kerabat dekat atau family }\end{array}$ & $\begin{array}{l}\text { Kaum Perantau dan } \\
\text { Pekerja keras. }\end{array}$ & $\begin{array}{l}\text { Tidak terlalu } \\
\text { umum dijumpai, } \\
\text { Bersifat kelompok }\end{array}$ \\
\hline 2 . & $\begin{array}{l}\text { Pengalaman dan latar sosial secara } \\
\text { individual yg dipengaruhi kehadiran } \\
\text { the generalized others termodifikasi } \\
\text { jadi new significant others; sahabat, } \\
\text { rekan kerja/bisnis, rekan organisasi, } \\
\text { tetangga dll. }\end{array}$ & $\begin{array}{l}\text { Seorang Profesional } \\
\text { dan } \\
\text { aktivis }\end{array}$ & 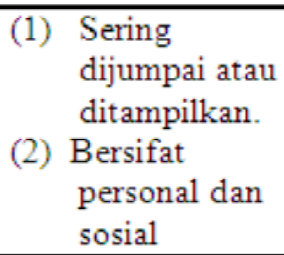 \\
\hline
\end{tabular}

pipi khusus untuk perempuan sebagai tanda akrab dan solidaritas. Penampilan orang Muna yang dominan ditunjukkan melalui cara berpakaian rapi, batik, jas / blaser, busana muslimah, bahkan dengan sedikit motif etnik. Ekspresi wajah orang Muna yang dominan ditunjukkan dengan senyuman, dan bersahaja sebagai pertanda sikap persahabatan, persaudaraan, dan keterbukaan yang tulus.

Sedangkan pada peristiwa komunikasi dengan etnik lain, khususnya Sunda, orang Muna cenderung melakukan pengelolaan kesan (impression management) melalui peminjaman budaya Sunda. Perilaku verbalnya didominasi variasi penggunaan bahasa Indonesia, kata, atau istilah bahasa Sunda secara bergantian termasuk penyebutan nama gelar. Demikian juga dengan perilaku nonverbal yang menonjol ditunjukkan dengan penggunaan bahasa secara impresif, dengan nada suara yang cenderung merendah dan lembut, jabatan tangan erat, senyuman, pelukan dan mencium persahabatan, penggunaan pakaian resmi dan rapi.

\subsection{Pembentukan dan Penggunaan "Setting" Komunikasi}

Setting komunikasi yang dibentuk dan dipergunakan orang Muna dalam berbagai peristiwa komunikasi di Bandung, dimulai dengan munculnya orientasi pengaturan setting, baik yang bersifat kelompok maupun personal, kehadiran orang lain dan keterlibatan dalam berbagai perisatiwa komunikasi. Lebih jelasnya dapat dilihat pada tabel 3.

Kedua orientasi pengaturan setting komunikasi yang dibentuk dan dipergunakan orang Muna dalam berinteraksi yang menonjol, yakni: (1) didasarkan pada keanggotaan dan kesetiaan pada kelompok etnik asal, dan (2) didasarkan pada latar belakang sosial dan pengalaman yang dipengaruhi status dan peranan dalam masyarakat. Pada setting yang pertama, nilainilai, tradisi dan budaya etnik asal yang di bawah menjadi sumber rujukan utama dan pertama dalam mempertegas identitas etnik mereka. Pada konteks ini, orang Muna mengonstruksi dirinya sebagai etnik minoritas, pribadi Muna di daerah rantau, sehingga penyebutan identitasnya kaum perantau, pekerja keras, santun dan tabah terhadap cobaan hidup. Sementara, pada setting komunikasi kedua, orang Muna menunjukkan diri sebagai pribadi yang aktif, ulet, terampil, berpengalaman dan berpendidikan. Kesibukan dan rutinitas pekerjaan yang dihadapi dalam bidang kerjanya serta dalam berbagai kegiatan sosial kemasyarakatan, dimanfaatkan untuk mempertegas eksistensinya

Tabel 3

Setting Komunikasi yang Dibentuk dan Penggunaan Orang Muna 
identitasnya saat ini, sebagai seorang aktivis dan profesional yang handal. Dengan demikian, setting yang pertama bersifat kelompok dan setting kedua bersifat pribadi, sebagai personal front baik di panggung belakang (back stage) maupun di panggung depan (front stage). Dengan kata lain, menurut Mulyana, (2002:114) sebagai situasi fisik yang harus ada ketika seseorang harus melakukan pertunjukan.

\subsection{Penggunaan Identitas Etnik}

Penggunaan identitas etnik Muna dalam proses interaksi dan komunikasi, secara umum selain dipengaruhi oleh satus perkawinan sesama orang Muna dan orang Muna dengan etnik lain, juga ditentukan oleh intensitas interaksi dan keterlibatan orang Muna dalam berbagai aktivitas, pekerjaan, organisasi, dan partisipasi sosial di masyarakat, sehingga perwujudan identitas etnik Muna Kedaerahan, etnik Muna Pragmatis, dan etnik Muna Religius, berbeda-beda, cenderung berubah-ubah, dan bersifat fleksibel. Bahkan, ketiga identitas etnik itu dipergunakan secara terpisah dan bersamaan. Perbedaan dan perubahan ketiga identitais tersebut tergantung pada perubahan orang-orang dan perubahan situasi dalam interaksi mereka. Secara khusus, penonjolan etnik Muna kedaerahan terjadi pada konteks intra etnik, dan penonjolan etnik Muna Pragmatis dan etnik Muna Religius terjadi pada konteks antaretnik. Tujuannya adalah untuk memupuk kesadaran etnik asal sebagai diri yang lalu dan untuk penyesuaian,

\section{Gambar 2}

\section{Model Simbolisasi Identitas Etnik orang Muna}

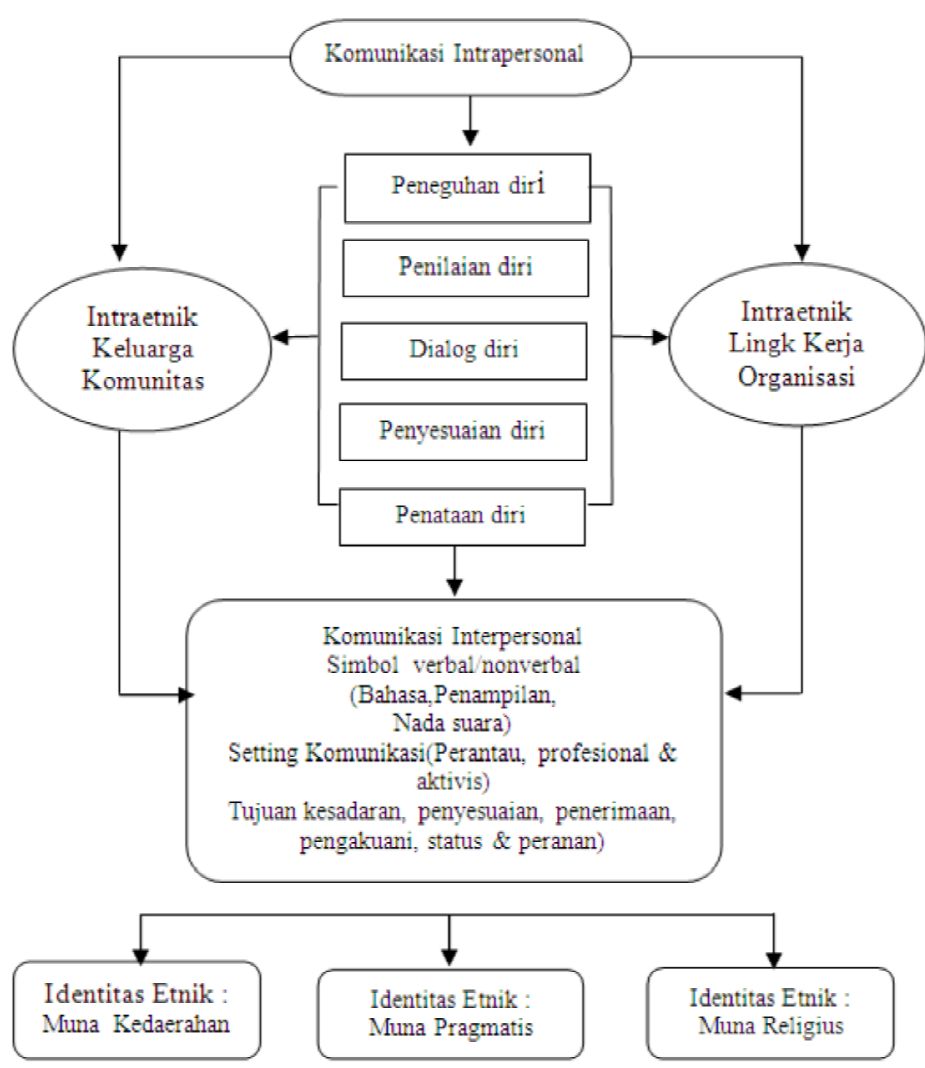

Sumber : Hasil Penelitian, 2008 
penerimaan, pengakuan serta gengsi, pribadi baik pada intraetnik Muna (back stage) maupun ekstretnik Muna (front stage).

Dengan demikian secara keseluruhan proses interaksi, komunikasi dan simbolisasi orang Muna di Bandung dalam mengonstruksi identitais etniknya dapat dimodelkan seperti gambar 2 .

\section{Penutup}

\subsection{Kesimpulan}

(1) Secara umum, proses identifikasi identitas etnik orang Muna dalam lingkungan etniknya berlangsung melalui mekanisme peneguhan diri dan penilaian diri. Sementara, dalam lingkungan ekstra etnik melalui mekanisme dialog diri, penyesuaian diri, dan penataan diri. Mekanisme tersebut membentuk tiga kategori identitas etnik, Muna Kedaerahan, Muna Pragmatis, dan Muna Religius.

(2) Simbol-simbol komunikasi verbal orang Muna dalam intraetniknya, terdiri atas penggunaan kata atau istilah bahasa Muna, bahasa Indonesia dan penyebutan nama gelar di depan nama. Sementara, dalam ekstra etniknya, menggunakan bahasa Indonesia dan kata atau istilah bahasa Sunda secara impresif dan halus atau melembut. Simbol komunikasi nonverbal orang Muna dalam intraetnik Muna diungkapkan melalui bahasa yang lugas dan tinggi disertai penampilan yang bersahaja. Di luar etniknya, simbol nonverbal ditunjukkan dengan bahasa yang halus, lembut, serta didukung penampilan fisik yang bersahaja dan berbusana yang rapi dan modern.

(3) Setting komunikasi yang dibentuk dan dipergunakan orang Muna meliputi: (1) didasarkan pada keanggotaan dan kesetiaan pada kelompok etnik asal, dan (2) didasarkan pada latar belakang sosial dan pengalaman yang dipengaruhi status dan peranan dalam masyarakat. Setting yang pertama bersifat kelompok dengan sebutan kaum Muna perantau dan pekerja keras, dan setting kedua bersifat pribadi dengan sebutan orang profesional dan aktivis. Sebutan tersebut sebagai personal front baik di panggung belakang (back stage) maupun di panggung depan (front stage).

(4) Penggunaan ketiga identitas dimaksud (Muna Kedaerahan, Muna Pragmatis dan Muna Religius), berlangsung secara berbeda-beda dan cenderung berubah-ubah mengikuti perubahan orang-orang dan situasi berkembang dalam interaksi. Perubahan perbedaan penggunaan ketiga identitas etnik tersebut bertujuan memupuk kesadaran, penyesuaian, penerimaan, pengakuan dalam etniknya dan dalam masyarakat. Penonjolan atau penggunaan salah satu identitas etnik bukan dimaksudkan untuk mengganti identitas lama, melainkan kesinambungan identitas etnik terhadap situasi yang baru.

\section{Daftar Pustaka}

Barth, Fredrik. 1988. Penerjemah: Nining I. Soesilo, Kelompok-Kelompok Etnik dan Batasannya, Jakarta: UI-Press.

Dilla, Sumadi. 2007. Komunikasi Pembangunan, Pendekatan Terpadu. Bandung: Simbiosa.

Goodman, Neal R. 1994. Cross Cultural Training for the Global Executive, Dalam Richard W. Brislin dan Tomoko Yoshida, ed, Improving Intercultural Communication, Modules. Thousand Oaks: Sage.

Gudykunst, William B, dan Young Yun Kim. 1992. Communicating with Strangers: An approach ti Intercultural Communication. Edisi ke 2, New York: McGraw-Hill.

Hall, Edward T. Dan William Foote Whyte. 1996. "Komunikasi Antarbudaya: Suatu Tinjauan Antropologis." Dalam Deddy Mulyana dan Jalaluddin Rahmat, ed. Komunikasi Antarbudaya: Panduan Berkomunikasi dengan orang-orang yang berbeda budaya. Bandung: Remaja Rosdakarya. 
Hofstede, Geert. 1994. Cultures and Organization: Intercultural Cooperation and its Importance for Survival. London: HarperCollins.

Hogg, M.A. \& Abram, D.1988. Social Identification: A Social Psychology of Intergroup Relation and Group Processes. London: Routledge.

Liliweri, Alo. 2001. Gatra-Gatra Komunikasi Antarbudaya. Yogyakarta: Pustaka Pelajar.

Mulyana D. 2002. Metodelogi Penelitian Kualitatif. Paradigma Baru Ilmu Komunikasi dan Ilmu Sosial Lainnya. Bandung: Remaja Rosda Karya.
2004. Komunikasi Efektif: Suatu Pendekatan Lintas Budaya. Bandung: Remaja Rosda Karya.

Solatun. 2007. Metodelogi Penelitian Komunikasi: Contoh-contoh Penelitian Kualitatif dengan pendekatan Praktis. Bandung: Remaja Rosda Karya.

Suparlan, Parsudi 1999, Masyarakat Majemuk dan Hubungan Antarsuku Bangsa. Jakarta: Gramedia.

Tubbs, Stewart L, dan Sylvia Moss. 1996. Human Communication I dan II, edisi Bahasa Indonesia, Penerjemah Deddy Mulyana. Bandung: Remaja Rosdakarya. 